Karl W. Schwarz

\title{
REFORMATOR IZ NOTRANJE AVSTRIJE: PRIMOŽ TRUBAR IN JUŽNOSLOVANSKI TISK BIBLIJSKEGA ZAVODA V URACHU'
}

\section{Uvod}

»Brez tiska ni reformacije." Ta ugotovitev zgodovinarja reformacije Bernda Moellerja $(1979,30)$ je zadela v črno. Med letoma 1517 in 1530 je izšlo skoraj 30.000 manjših ali večjih tiskanih publikacij, v skupni nakladi vsaj 20 milijonov izvodov (Weismann 1986, 12) - lahko sklepamo, da tri četrtine na račun reformacijskega gibanja. Prišteti je treba še iznajdbo »letakov«, ki so v množičnih nakladah za majhen denar širili aktualne teme (Köhler 1981). Christoph Weismann opozarja še na eno novost, ki zasluži pozornost: male tiskarne, ki so živele od ponatisov - ni bilo tako redko, da od dvajset, trideset ponatisov, zlasti Luthrovih spisov. Tudi tiskarna Johanna Singrienerja na Dunaju je dobro zaslužila s takimi ponatisi (Lang 2017, 128-49). Tretja novost so bili potujoči knjigarnarji, mali potujoči trgovci, ki so ponujali svoje brošure in letake na tržnicah, pred cerkvami, na množičnih shodih ali pa hodili od vrat do vrat in tako poskrbeli za hitro razširjanje reformacijskega tiska. »Tisk in reformacija sta nerazdružna celota, in kar označujemo kot kulturni dosežek reformacije, je v veliki meri sad blagoslovov Gutenbergove iznajdbe.« (Weismann 1986, 13)

Weismann ni bil prvi, ki je razvil to tezo tudi ob pogledu na južnoslovansko reformacijsko literaturo. Zaradi posebne povezanosti med 1 Prof. dr. Feliksu Bistru za bližajoči se 8o. rojstni dan. 
vojvodinama Kranjska in Württemberg je spodbuda za preučevanje te veje reformacije prišla iz Tübingena. ${ }^{2}$ Omeniti velja tamkajšnjega bibliotekarja Christiana Friedricha Schnurrerja (1742-1822) s konca 18. stoletja (Schnurrer [1799] 1989), katerega knjižno zbirko je leta 1814 uspel pridobiti dunajski dvorni bibliotekar Jernej Kopitar (1780-1844) (Lukan 1994, 677-78). Kot lahko vidimo iz izdaje virov, ki jo je leta 1874 pripravil bibliotekar Ivan Konstrenčić, je poleg Tübingena postala središče zbiranja in raziskovanja te literature tudi Dunajska dvorna biblioteka (Hüttl-Hubert 2000, 34; 2004, 93-108; 2007, 215). Proti koncu 19. stoletja je zaslužen predvsem ljubljanski pastor Theodor Elze (1823-1900), ki ni le izdal pisem Primoža Trubarja (Elze [1897] 2017), temveč je zložil še mnogo drugih zidakov slovenske reformacijske zgodovine in sestavil zbirko Trubarjevih del (Dolinar in Schwarz 2016, 311). Žal pa ni napisal Trubarjeve biografije. Zanjo je šele po drugi svetovni vojni poskrbel vodja ljubljanske univerzitetne knjižnice Mirko Rupel (1901-1963): prvi izdaji v Beogradu (1960) je sledila slovenska leta 1962, ki jo je leta $1965 \mathrm{~V}$ nemščino ${ }^{3}$ prevedel Balduin Saria (1893-1974).

Še med drugo svetovno vojno sta južnoslovanski reformaciji svoj interes posvetila dva kasneje slavna znanstvenika: teolog Ernst Benz (19071978) in zgodovinar Günther Stökl (1916-1998). Benz je raziskoval življenje in delo prominentnega eksulanta Hansa Ungnada (1493-1564) in njegov pomen za reformacijo pri južnih Slovanih ter pri tem razgrnil »religiozne in jezikovno teološke nagibe prevajanja in tiskanja v južnoslovanskih jezikih v času reformacije (Benz [1939] 1949, 141-208). Drugi je v svoji doktorski disertaciji (Breslau 1940) tematiziral »nemško-slovansko jugovzhodno mejo cesarstva v 16 stoletju«, ki še danes sodi v referenčno literaturo (Suppan 2002, 163-82, 422-23). Za reformatorja Slovencev se zanimajo teologi, zgodovinarji, jezikoslovci in kulturologi kot tudi raziskovalci knjižnega tiska. ${ }^{4}$

2 O tem izčrpno v delih, ki so jih pripravili Brecht in Ehmer (1984, 417-18), Kluge (1995), Lorenz, Schindling in Setzler (2011).

3 Rupel 1965. Naj opozorim še na nemški prevod dela Jožeta Javorška Primož Trubar, ki je primer poljudno pisane biografije z znanstvenimi ambicijami (Javoršek 2011).

4 Najnovejše knjižno delo o Trubarju je Giesemannova analiza njegove teologije (Giesemann 2017). [O tem delu pišemo v številki 27 (2018) revije Stati inu obstati, str. 161-88]. 


\section{Dva reformatorja iz habsburških dežel}

Iz habsburških dežel pa ni izhajal le Slovenec Primož Trubar (15081586), ampak tudi mnogo mlajši Hrvat Matija Vlačić (1520-1575), bolj poznan kot Matthias Flacius Illyricus, rojen v Labinu/Alboni v Istri (Ilić 2014; Sakrausky [1970] 1981). Bil je Luthrov učenec, ki je po reformatorjevi smrti leta 1546 vodil teološko šolo gnesioluteranov v zagrizenem teološkem spopadu s Philippom Melanchthonom (1497-1560) in filipisti. »Flacijanski spori« naj bi do temeljev pretresli wittenberško reformacijo. Vlačić pa ni bil pomemben le zaradi boja za ohranjanje čistosti luteranskega nauka. Bil je prvi zagovornik verbalne inspiracije Biblije in zaslužen za zbirko zgodovinskih spisov Magdeburger Centurien; kot tak je bil utemeljitelj evangeličanskega cerkvenega zgodovinopisja in znanstvene hermenevtike. Kot historiograf je bil $\mathrm{v}$ tesnih stikih $\mathrm{z}$ dunajsko dvorno biblioteko, posebej s Casparjem Niedbruckom (1525-1557), ki mu je pogosto dobavljal rokopise za Magdeburške centurije (Ilić 2016). Vlačić se je večkrat mudil v Notranji Avstriji, v Ljubljani in na Koroškem; leta 1562 je pripravil osnutek načrta, kako bi celovški Colegium sapientiae et pietatis (Kolegij modrosti in pobožnosti) dogradili v "pol univerzo«, Semiacademiolo (Baum 1991; Leeb 2009, 268). Ta projekt naj bi utrdil reformacijo v Notranji Avstriji in za to izkoristil stičišče nemškega, slovansko-ilirskega in italijanskega kulturnega prostora. Flacijanski spori so sicer odmevali tudi v Notranji Avstriji in so celo obremenili življenje luteranske občine v Ljubljani (Sakrausky [1968] 1981).

Še o Primožu Trubarju. ${ }^{5}$ Rojen je bil v vasi Raščica v župniji Škocjan pri Turjaku kot Primož Malnar; med letoma 1520 in 1526 je prevzel družinsko ime Trubar po materi in ga v nemškem okolju pisal kot Truber (Golec 2011). Izobraževal se je v mestni latinski šoli na Reki in v šoli pri sv. Petru v Salzburgu, kjer je kot opat deloval Luthrov učitelj in mentor Johannes Staupitz (1469-1524); dejansko pa se je teološko izobrazil pravzaprav na škofovskem dvoru v Trstu. Tam je bil kot škof po-

5 Naj spomnim, da lahko o njem danes beremo tudi v tako različnih publikaci-

jah, kot so revija Lutheran Quarterly (Ilić 2008), veliki leksikon o reformatorjih (Schindling 2014, 247-52) ali zbornik, ki je izšel v Moskvi (Schindling 2016). 
memben humanist Pietro Bonomo (1458-1546) (Simoniti 2008, 282-83), ki je skrbel za Trubarjevo izobrazbo, ga spodbudil k branju Parafraz Erazma Rotterdemskega (1469-1536) in mu odprl oči za humanistično misel (Simoniti, 286-88): Sveto pismo bi moralo biti dostopno vsakemu in zato prevedeno v vsakokratni ljudski jezik. V Trstu se je Trubar srečal s središčno zahtevo humanistov, ki jo je udejanjil v drugi polovici 16. stoletja - za »svoje« kranjsko ljudstvo, za »moje ljube Slovence« (ki jih je kot take tudi prvi nagovoril).

Bonomo je Trubarja seznanil z aktualno reformatorsko literaturo, deli Heinricha Bullingerja (1504-1575), Zwinglijevega naslednika v Zürichu, in deli Jeana Calvina (1509-1564). Poslal ga je na študij na Dunaj, kjer je bil vpisan v letni semester 1528. Bil je priča sežigu na grmadi Balthasarja Hubmaierja (1485-1528), obsojenega na krivoverskem procesu (Rothkegel 2004). Zaradi turške nevarnosti se je vrnil v Trst. Bonomo je poskrbel, da je Trubar po duhovniškem posvečenju leta 1530 dobil župnijo in vir dohodkov v Laškem. Leta 1533 je bil poklican za pridigarja v stolnico sv. Nikolaja v Ljubljani, kjer je srečal reformaciji naklonjene člane kapitlja (Grdina 2006, 13; Rajšp 2008): stolničnega prošta Leonarda Mertlica, generalnega vikarja Jurija Dragoliča in Paula Wienerja (1495-1554), ki si je dopisoval z reformatorji v Nemčiji. Reformatorski krožek, ki so mu pripadali tudi pisar deželnih stanov Mathes Klombner, mestni sodnik Vid Khisel in učitelj Lenart Budina (1500-1573), je bil kmalu opažen in deležen pregona. Trubar se je pravočasno umaknil v Trst, kjer je imel kot Bonomov tajnik še naprej dostop do reformatorske literature in bil napoten na branje Calvinove Institutio religionis cristianae. Leta 1542 je postal ljubljanski škof reformaciji naklonjeni Franc Kacijaner (1501-1543), ki je Trubarja vključil v stolnični kapitelj, kar je bil takrat najvišji cerkveni položaj, ki ga je bil lahko deležen neplemič. Izbral ga je za osebnega spovednika in mu v oporoki zapustil številne reformatorske spise, med njimi tudi dela württemberškega reformatorja Johannesa Brenza (1499-1570). Po porazu protestantov v šmalkaldski vojni 1546 so Habsburžani tudi v Ljubljani ostreje nastopili proti reformatorskim novostim. Novi škof Urban Texstor (1491-1558) je poskrbel za zaporni nalog za člane stolničnega kapitlja. Trubar je zopet pravočasno ubežal in odšel najprej k Veitu 
Dietrichu (1506-1549), glavnemu župniki cerkve sv Sebalda v Nürnbergu. Ta je prav takrat izdal Agend-Büchlein für die Pfarr-Herren auff dem Land [Agenda za župnike na deželi] (Nürnberg 1543), tako rekoč prvo in izčrpno oporo za »staroverske« duhovnike, ki so se pridružili reformaciji. Trubar jo je zelo natančno preučil in sadove tega branja lahko najdemo že v njegovem Katekizmu 1550.

Verska razsežnost Trubarjevega dela je bila v predvojni in povojni Jugoslaviji večkrat prezrta, ker je bila tuja modernemu mišljenju ali pa je skozi nacionalno obarvana očala ni bilo mogoče prepoznati (Jerše 2013). Postal je zelo popularen kot ustvarjalec slovenskega knjižnega jezika in »oče slovenske književnosti«. Na tem mestu naj opozorim, da njegov portret krasi slovenske eurokovance in da dan reformacije, 31. oktober, v Sloveniji velja za državni praznik, čeprav je evangeličansko-luteranska cerkev številčno čisto majhna in ima svoje težišče v Prekmurju, ki je bilo šele leta 1919 oddeljeno od Madžarske in priključeno Kraljevini Jugoslaviji.

Visoko vrednotenje in spoštovanje reformatorske tradicije je pripisati dejstvu, da so prve slovenske knjige identične z reformatorskimi tiski. Gre za Trubarjev luteranski slovenski katekizem Catechismus In der Windischen Sprach iz leta 1550. Zvezanega skupaj z Abecednikom in malim katekizmom $\mathrm{v}$ slovenskem jeziku iz istega leta ter drugo verzijo Abecednika (Abecedarium. Ene Buqvice 1555) imamo na Dunaju in kot unikat sodi med največje dragocenosti Avstrijske nacionalne biblioteke. Okoliščine, v katerih so ti dragulji prišli v Palatina viennensis, so natančno raziskane in predstavljene (Hüttle-Hubert 2008) ter dokazujejo pomen te biblioteke za preučevanje slovenske reformacije. Njena zbirka 35 izvirnih tiskov južnoslovanske reformacije je druga največja na svetu. Tako je razumljivo, da so sodelavci dvorne biblioteke postali specialisti za reformacijsko literaturo južnih Slovanov, posebej še za Primoža Trubarja: poleg že omenjenih Kopitarja in Kostrenčića še Franc Miklošič (1813-1891), Ivan Prijatelj (1875-1937), France Kidrič (1880-1950) in nazadnje Eva Hüttl-Hubert. ${ }^{6}$

6 O tem pričajo starejša dela (Prijatelj 1908; Kidrič 1919) in novejše študije (HüttleHubert 1998; 2003). 


\section{Prva slovenska knjiga ...}

... je bila natisnjena anonimno in $\mathrm{z}$ izmišljeno navedbo tiskarja in mesta tiskanja (gedruckt inn Sybenburgen durch den Jernei Skuryaniz). Previdnost je bila posledica prepovedi tiskanja brez odobritve cenzorskega uradnika (po cesarskem mandatu iz leta 1548). V času t. i. Interima do pričakovanega koncila (Schorn-Schütte 2005) je bilo protestantom sicer dovoljeno obhajanje pod obema podobama in poročanje duhovnikov, vse druge konfesionalne spremembe pa naj bi opustili. Posledično si noben založnik ni upal tiskati njihovih verskih knjig. Doslej so bili raziskovalci prepričani, da je Trubarju kot pridigarju v Rothenburgu s posredovanjem njegovega rojaka Michaela Tiffernusa (1488/89-1555) uspel stik s tiskarjem Ulrichom Morhartom iz Tübingena (Vorndran 1977; Setzler 2011, 418; Schindling 2013, 178). Tako piše v vseh knjigah do leta 2013 in tudi v mnogih, ki so izšle v Trubarjevem jubilejnem letu 2008 (Zorn 2008). Potem pa je raziskovalec tiska Helmut Claus po inicialki L odkril, da se knjiga ni tiskala v Tübingenu, ampak v mnogo manjši tiskarni Petra Frentza v Schwäbisch Hallu (Weismann 2013; Ahačič 2014). Tiskana je v gotici, v t. i. frakturi.

Posebnega pomena je bil pri tem Trubarjev jezikovno-ustvarjalni dosežek. Obstajali so sicer že starejši (rokopisni) staroslovenski Brižinski spomeniki iz obdobja okrog leta 1000 (Pogačnik 1968), toda njihovi spovedni obrazci niso utemeljili knjižne tradicije. To je uspelo šele Trubarju (Jesenšek 2008) z njegovima Katekizmom in Abecednikom 1550 (druga, predelana izdaja leta 1555).

\section{Trubarjevo slovensko prevajanje Biblije}

S prevajanjem Biblije je Trubar začel kot župnik v cesarskem mestu Kempten, kamor se je preselil leta 1553. Da je postal prevajalec, je posledica "teženja« nekdanjega koprskega škofa Petra Pavla Vergerija (1494-1565), ki se je istega leta kot svetovalec vojvode Christopha Württemberškega nastanil v Tübingenu. Prizadeval si je za reformacijo na Poljskem in v 
Notranji Avstriji ter poizkušal Trubarja pridobiti za prevajanje v jezik(e) južnih Slovanov. Ta se je tega najprej otepal, ker da ne zna biblijskih jezikov, hebrejščine in grščine. Šele po premisleku in odločitvi, da bi pri prevajanju izhajali iz obstoječega Luthrovega prevoda, se je pustil prepričati. V tem so ga podprli tudi prijatelji iz Tübingena in Ljubljane. V pismu Bullingerju, datiranem 13. 9. 1555 v Reutlingenu, je zapisal, da mu je prevajanje Biblije naložila/poverila »celotna Cerkev njegove domovine« (Elze [1897] 2017, 19; Rajhman 1986, 23). V nemškem predgovoru k prevodu Nove zaveze je svojo odločitev in motivacijo podkrepil še s sklicevanjem na zavezanost vesti: »In ker mi je [...] od Boga po posebni milosti in po Kristusovi volji dano, da znam govoriti slovensko, kot se govori v deželi Kranjski in sem, kot veste, 17 let $\mathrm{v}$ tem jeziku pridigal v več krajih slovenskih dežel. Tako precej razumem latinsko, nemško in italijansko. Vse to in moja lastna vest so me prisilili k temu prevajanju.« [Redakcijski prevod iz nemščine v sodobno slovenščino]Tako se je posvetil prevajanju z veliko vnemo in s skrajno zbranostjo. Leta 1555 je kot prvi preizkus njegovega prevajanja Biblije izšel Evangelij svetega Matevža, prvič preveden $v$ slovenski jezik (Tübingen: Ulrich Morharts Erben 1555) - ne več v gotični frakturi, ampak v latinski antiqui. Po umrlem Ulrichu Morhartu (1495-1554) sta tiskarno podedovala sinova njegove vdove iz prvega zakona Oswald in Georg Gruppenbach; slednji je skrbel za izdajanje Trubarjevih del vse do posthumnega tiska prevoda Luthrove Hišne postile leta 1595 (Hüttl-Hubert 2003, 93). Sredi leta 1557 je bila Nova zaveza pripravljena za tisk v dveh delih, od katerih je bil obsežnejši prvi del, Prva polovica Novega testamenta, štirje evangeliji in dejanja apostolov iz izvrstnih in preizkušenih starih in novih latinskih, nemških in italijanskih prevodov, zdaj prvič pridno prevedena v običajni slovenski jezik [prevedeno iz nemščine v sodobno slovenščino]. To 860 strani dolgo besedilo je bilo tudi prvo, ki ga je podpisal s svojim imenom. Drugi del s Pismi apostolov mu je delal večje težave, saj v slovenščini ni mogel najti ustreznih izrazov za mnoge teološke pojme in si je zato pomagal $\mathrm{z}$ nem-

7 Tako piše Trubar v svojem nemškem predgovoru k prvi izdaji prevoda iz Novega testamenta 1557: glej Sakrausky 1989, 96 f: sledeči citat iz predgovora je prav tam na str. 104 (tudi Rupel 1965, 78). 
škimi. Zaustavila pa ga je še druga teološka težava. Vergerij, s katerim se je leta 1557 sprl in razšel, ga je pri württemberškem vojvodu zatožil, da so v njegovih knjigah velike zmote in heretične cvinglijanske izjave. ${ }^{8}$ Vojvoda Krištof je tiskanje tega dela zato nemudoma zaustavil. Trubar se je obrnil na Hansa Ungnada s prošnjo za pomoč in posredovanje. Ta mu je svetoval, naj pošlje svoja dotedanja dela na Dunaj takratnemu nadvojvodu in češkemu kralju Maksimilijanu s prošnjo za teološko presojo. Vse, kar je poslal na Dunaj, je dal Trubar natisniti kot: Register und summarischer Innhalt, aller der Windischen Bücher, die von Primo Trubero, biß auff dieß 1561 Jar in Truck geben seind. Und jetztundt zum anderen, in der Crobatischen Sprach mit Zweyerley Crobatischen Geschrifften, nämlich mit Glagola und Cirulitza, werden getruckt [...] Getruckt zu Tübingen bey Ulrich Morharts Wittib 1561. [Register in sumarična vsebina vseh slovenskih knjig, ki jih je Primož Trubar dal natisniti do leta 1561. Zdaj pa tudi $v$ hrvaškem jeziku, $z$ dvema hrvaškima pisavama, namreč z glagolico in cirilico (...), natisnjeno v Tübingenu 1561]Ta register velja za začetek pisanja slovenske literarne zgodovine. Presoja poslanih spisov je bila opravljena zelo hitro: cenzor Hrvat Peter Skalić (1534-1575) je potrdil pravovernost vseh publikacij, kritiziral pa je prevode, izbrano ortografijo in samo izbiro jezika (Katičić 2007), kar je Trubarja precej razjezilo. Vsekakor pa je lahko zdaj, v drugi polovici leta 1561, hitro izšlo Pismo Rimljanom in bilo poslano v Ljubljano.

\section{»Biblijski zavod» v Urachu - in Hans Ungnad von Sonnegk}

Na tem mestu moram zdaj vstaviti poglavje o še enem pobudniku in podporniku južnoslovanskega prevajanja Biblije, nekdanjem štajerskem deželnem glavarju Hansu Ungnadu Ženeškem (Zimmermann 1981). Ta je imel bogate izkušnje iz vojne z Osmani že kot deželni glavar, vicedom celjske grofije in nadzornik Varaždina, a tudi kot vojskovodja

8 Eva Hüttl-Hubert (2003, 94-96) opozarja na Vergerijev spis A gl' Inquisitori che sono per l'Italia. Del Catalogo di libri eretici, stampato in Roma nell'Anno presente M. D. LIX., ki poizkuša pri papeški inkviziciji Trubarja očrniti kot heretika. 
v cesarskih službah. Leta 1555 je iz versko-konfesionalnih razlogov sam odstopil s političnih funkcij in emigriral v Nemčijo. Že omenjani vojvoda Krištof ga je vzel za svojega svetovalca in mu dal na razpolago samostansko poslopje pri cerkvi sv. Amanda v Urachu. Tam je ustanovil Windische, Chrabatische und Cirulische Truckherey, ki je začela z delom leta 1561 in delovala do njegove smrti 1564 (v oklepaju povejmo, da je bila Ungnadova privatna knjižnica predana v oskrbo Baselske univerzitetne biblioteke) (Heilingsetzer 2005). Sicer nepopolna zbirka tiskov iz Uracha (17) se nahaja v Tübingenu (Vorndran 1977, 3), ki je imel najtesnejše zveze z jugovzhodom Evrope že od časa Tiffernusa, Vergerija, Ungnada in Trubarja in ki je zato nota bene lahko vzpostavil tudi prve stike z vzhodno cerkvijo (Weismann 1986, 34; Benga 2003).

Ungnada so vodile misijonarske ambicije. Kot privrženec gnesioluteranske misijonske strategije (Benz 1949, 192-93, 275, op. 80; Leeb 2009, 257) je hotel prispevati k spreobrnjenju južnih Slovanov in celo Turkov. V prošnji za pomoč je zapisal, da gre zavodu v Urachu za "povečanje Božje slave, spreobrnjenje, odrešenje in blaženost ubogih, nevednih in brezbožnih Slovencev, Hrvatov in Turkov« (Weismann 1986, 30). Stranski učinek tega bi bila stabilizacija vojaških razmer na Balkanu in omejitev osmanske nevarnosti (Knüppel 2004). V uraško podjetje je vložil vse svoje premoženje; za voditelja zavoda je bil imenovan Primož Trubar. Trubarju sta ob strani stala dva hrvaška teologa, Štefan Konzul (1521-1579) in Antun Dalmata (1500-1579), ki sta njegova besedila prevedla v hrvaščino; sodelovanje je bilo zelo težavno, obremenjevale so ga različne jezikovne koncepcije (Jembrich 1995), ljubosumnosti in morda tudi konkurenčna zavist. Za financiranje sta skrbela Ungnad in Vergerij; notranjeavstrijsko plemstvo in stanovi Notranje Avstrije so bogato darovali za to velikopotezno razširjanje Biblije. Med letoma 1560 in 1564 je bilo natisnjenih 37 del v 30.000 izvodih, od tega 4 v slovenščini, $13 \mathrm{v}$ srbohrvaščini v glagolici, $7 \mathrm{v}$ srbohrvaščini v cirilici, $5 \mathrm{v}$ srbohrvaščini $\mathrm{v}$ latinici, $6 \mathrm{v}$ italijanščini in $1 \mathrm{v}$ nemščini (Ehmer 2011, 211; Lagler 2011). ${ }^{9}$ Vsa ta dela so bila posamično predstavljena in obravnavana $\mathrm{v}$ razpra-

9 Glej tudi katalog razstave v Brezah (Fresach) »Primož Trubar - Spracheiniger und Reformator" (Hanisch-Wolfram in Pflaum 2012). 
vah Elzeja, Stökla, Rupla, nekdanjega vodje tübingenške univerzitetne knjižnice Rolfa Vorndrana (1920-1997), sedanjega vodje Wilfrieda Laglerja in drugih. ${ }^{10}$

\section{Trubarjev Cerkveni red (1564)}

Cerkveni red Primoža Trubarja je najstarejši pisani pravni dokument Slovencev, čeprav ni nikdar stopil v veljavo. Odkritje izvoda Cerkovne ordninge v mestni knjižnici v Memmingenu leta 2014 je bilo prava senzacija za raziskovalce pravne in cerkvene zgodovine (vezan je bil v pergamentni list Catholicona avtorja Johannesa Balbusa, Augsburg 1496) (Oppitz in Weismann 2014; Schwarz 2015). Senzacija je bilo zato, ker je bil večji del od 400 v Tübingenu natisnjenih izvodov v Vojvodini Kranjski žrtev protireformacije. Preživelo jo je samo nekaj izvodov s posvetili na knežjih dvorih in njihovih bibliotekah. Pri bombardiranju Dresdna leta 1945 je bil uničen edini poznani izvod v Saški deželni knjižnici, ki ga je uporabljal in opisal Theodor Elze (1894, 145-48, 151); kasneje ga je uporabil, opisal in preučil France Kidrič v svojem habilitacijskem delu (1919) in se nanj leta 1927 opiral slavist Matija Murko (1861-1952). Leta 1971 je Christoph Weismann v Bibliotheca Apostolica Vaticana odkril še en izvod, ki se je izvirno nahajal v Bibliotheca Palatina v Heidelbergu. Weismann ga je preučil in predstavil javnosti, tudi zamotano zgodovino njegovega posedovanja (Weismann 1972). Ta izvod je bil predloga za faksimilno izdajo, ki jo je pripravila založba Rudolfa Trofenika (19111991) v Münchnu 1973 in za tekstnokritično izdajo v okviru Trubarjevih Zbranih del v Ljubljani (Grdina in Vinkler 2005). Novoodkriti izvod v Memmingenu je najbolje ohranjen in odpravlja težave z zgubljenimi deli besedila v prejšnjem izvodu. Bil je digitaliziran ${ }^{11}$ in je tako olajšal nadaljnje raziskovanje.

10 Od najstarejših do novejših pregledov izpostavimo: Elze 1895, 127-28; Stökl 1940, 41-42; Rupel 1965, 293-99; Berčič 1968; Vorndran 1977, 9-10; Grüll in Monok 1992.

$11 \mathrm{Http}: / /$ stadtarchiv.memmingen.de/trubar.html. 
Cerkovna ordninga je bila prvi evangeličanski cerkveni red v katoliških habsburških deželah, se pa zaradi katoliške konfesionalne opredelitve deželnega kneza ni mogel obdržati; neslovenske cerkvene občine na Štajerskem, Koroškem in Krajnskem ga seveda sploh niso sprejele. Za notranjeavstrijski protestantizem, ki mu je bila $\mathrm{z}$ bruško versko pomiritvijo 1572/1578 dovoljena verska svoboda, je izdelal cerkveni red profesor iz Rostocka David Chytraeus (1530-1600). Stanovi so ga podpisali 20. -21. februarja 1578. Tudi ta cerkveni red je že po sedmih letih padel pod udarci protireformacije, saj je bil že v samem bruškem libellu obseg dopuščene verske svobode sporen, kajti protestantski deželni stanovi so versko svobodo razumeli drugače kot katoliški deželni knez, ki jo je reduciral na svobodo vesti (Reingrabner 2007, 56).

Ob Cerkovni ordningi lahko pokažemo, kako je hotel Trubar organizirati notranjo ureditev cerkvenega življenja $\mathrm{v}$ »erkvi Božji slovenskega jezika.$^{12}$ Tej Cerkvi je posvetil svoj prevod Matejevega evangelija (1555). S to ekleziološko izjavo je upošteval reformatorsko spoznanje, da je Cerkev creatura verbi divini [stvaritev Božje besede], ki se konstituira samo skozi oznanjevanje Božje besede in zaradi njega. Hkrati pa ima ta opredelitev pri Trubarju tudi topografsko težo, saj Trubar kot področje, kjer prebivajo njegovi ljubi rojaki, označi Krajnsko, spodnjo Štajersko, Koroško, Goriško, Metliko, Kras in Istro. Svoj cerkveni red ni navezal na topografski prostor, ampak na jezikovno-sociološkega. Veljal naj bi tam, kjer bi bil razumljen in sprejet, torej med njegovimi lubimi Slovenci.

To nalogo si je Trubar zastavil iz posebnega razloga: leta 1560 je bil zopet poklican $\mathrm{v}$ Ljubljano, in sicer za superintendenta cerkvene organizacije, ki so jo vzdrževali pretežno protestantski kranjski deželni stanovi (L. Ilić in A. Ilić 2017). Za vzgled si je vzel württemberški Veliki cerkveni red in ga prilagodil.

Za praktično uporabo $v$ cerkvenem vsakdanjiku je pripravil besedilo Articyli oli dejli (Tübingen 1562), sestavljeno iz treh reformatorskih veroizpovedi: Confessio Augustana (1530), Confessio Virtembergica, ki jo je pripravil Brenz in je bila predložena tridentinskemu koncilu (1552), ter

12 Tako Trubar poimenuje naslovnika svojega posvetila k prevodu Matejevega evangelija. O tem Kerševan 2013, 155-66. 
Confessio Saxonica (1550), prav tako pripravljeno za koncil. Toda Trubar ni pripravil nekakšnega sinopsisa treh veroizpovedi, ampak pravo »veroizpovedno harmonijo « s podnaslovom: Drey Christliche Confessionen [...] in diß windische Buch zusammengezogert [»tri krščanske veroizpovedi (...), združene $v$ tej slovenski knjigi«]. Za to je bil spet deležen očitkov, da meša veroizpovedi in da je s konfesionalnega vidika sumljiv. Pripisovali so mu, da hoče posredovati med Zürichom in Wittenbergom, in sumili, da njegov Cerkveni red ni strogo v skladu $\mathrm{z}$ augsburško veroizpovedjo ter da prav pri spornem vprašanju evharistije vnaša cvinglijansko teologijo. Mecen je zato zahteval, da se Cerkveni red prevede v nemščino in preveri pravovernost njegove usmeritve. To je tiskanje izjemno zavleklo. Knjiga je potem izšla brez predvidenega predgovora in brez že pripravljene naslovne strani (Žnidaršič Golec 2011).

Konfesionalno-politični položaj v Notranji Avstriji je bil povsem drugačen od Württemberga, kjer je cerkveni red uvedel deželni knez, ki je podpiral reformacijo. Tu je od leta 1564 vladal Karel II., mlajši sin cesarja Ferdinanda I. Njegov cilj je bil zatreti reformatorske spremembe v Cerkvi v skladu z dolgoročno strategijo; računal je na papeško nunciaturo in katoliško univerzo v Gradcu (1585), ki so jo vodili jezuiti (Schindling 2011, 298).

Nameravane rekatolizacije pa ni mogel uresničiti zaradi osmanske vojaške grožnje. »Turek je za luterane sreča, sicer bi z njimi drugače postopali.« Ta stavek, ki se pripisuje Karlovemu dvornemu kaplanu, je pri opisu versko-politične konstelacije v Notranji Avstriji zadel v črno (Metzler-Andelberg 1994, 222). Ker je bil deželni knez pri pobiranju davkov odvisen od državnih stanov, je moral previdno krmariti in posebej $\mathrm{v}$ času vojaškega stanja s Turčijo protireformacijski program podrediti skrbi za obrambo dežele.

Ob Trubarjevem Cerkvenem redu pa ni dopustil nobenega dvoma in se je takoj skliceval na svoj ius reformandi, kot je bil opredeljen v Augsburškem verskem miru 1555 (cuius regio, eius religio). Cerkveni red ni bil uveljavljen, saj ga je Karl II. dal nemudoma zapleniti. Stanove, ki so proti temu protestirali, je ostro zavrnil: "Nach den reichsconstitutionen und dem religionsfrieden stehe es nich ihnen, sondern ihm, 
dem landesfursten $z u$, der religion halber maß und ordnung zu geben, ihnen aber, denselben zu gehorsamert" [Po predpisih cesarstva in verskega miru ne pripada vam, ampak njemu, deželnemu knezu, da skrbi glede religije za mero in red, na vas pa je, da ste pri tem poslušni] (Elze [1897] 2017, 443). Skliceval se je na svoj odlok o veroizpovednem izobčenju, ki ga je izdal v smislu protireformacije: »Es gereiche ihm, solche eigenwillige anmaßung zu großem missfallen, und behalte er sich die strafe gegen verusacher der publicierung dieser vermeinten kichenordnug vor" [Na njem je, da se zoperstavi taki samovoljni aroganci in da kaznuje povzročitelja objave tega dozdevnega cerkvenega reda] (Elze [1897] 2017, 443). Primož Trubar, od stanov poklicani superintendent kranjske cerkve, je moral spet pobegniti in že tretjič oditi v izgnanstvo v Württemberg.

\section{Dalmatinov prevod Biblije}

Ne pri Morhartu v Tübingenu, ampak v Wittenbergu je končno izšla po svojem prevajalcu Juriju Dalmatinu (1547-1589) poimenovana celotna Biblija. Z imenitnimi lesorezi opremljeno delo ima letnico 1584. Natisnjeno je bilo v tiskarni Hans Kraffts Erben v nakladi 2.000 izvodov. Velja za vrh južnoslovanskega knjižnega tiskanja v Nemčiji in teološki ter literarni mejnik slovenskega protestantizma, ki je vplival na razvoj slovenskega jezika v slovničnem, stilističnem in umetniško-poetičnem pogledu. Gradil je na predhodnih delih Trubarja, ki je med letoma 1555 in 1577 objavil svoj prevod novozaveznih knjig in psalterja v več komentiranih delnih izdajah. Dalmatin je tako dokončal prevajalsko delo svojega učitelja (Sakrausky 1981; Weismann 1986, 3031) in je v tem smislu v navezi tudi $\mathrm{z}$ "Biblijskim zavodom " v Urachu. Izhaja iz Krškega; šolal se je najprej pri Adamu Bohoriču (1520-1598), avtorju prve slovenske slovnice (1584), in kot štipendist Tiffernovega sklada prišel v Tübingen, kjer je bil leta 1569 promoviran kot magister. Od leta 1572 je deloval kot nemški in slovenski pridigar v Ljubljani. Leta 1575 je v pravkar ustanovljeni tiskarni Hansa/Janeza Mannela/ 
Manliusa/Mandelca kot svoj prvi prevod izdal svetopisemskega Siraha; leta 1578 je sledilo Peteroknjižje, 1580 Salomonovi pregovori (kot zadnja v Ljubljani natisnjena knjiga). Mandelčeva tiskarna, ki je v petih letih izdala 30 naslovov, je morala pod pritiskom oblasti zapustiti Ljubljano in se preseliti na zahodno Madžarsko (Kohnle 2011, 224).

Leta 1581 je Dalmatinov prevod pregledala komisija teologov in filozofov. Glavno delo pri jezikovnem pregledu in korekturah je opravil Bohorič. Kot stranski produkt je nastala njegova v latinščini napisana prva slovenska slovnica Articae horulae succisivae de Latinocarniolana literatura, ad latinae linguae analogiam accomodata [...] (Wittenberg 1584). Leta 1582 sta Dalmatin in Bohorič potovala v Wittenberg, da bi na kraju samem spremljala tiskanje Biblije. Danes je ohranjeno okrog 60 izvodov te izdaje, dva v Dunajski nacionalni biblioteki (HüttlHubert 2003, 114); od 300 na Koroško pripeljanih izvodov so ohranjeni vsaj trije, eden v muzeju v Fresachu (Ernst in Hanisch-Wolfram 2011, 503-04).

\section{S strani deželnih stanov vzdrževana Cerkev na Kranjskem ...}

... je obstajala do 27. oktobra 1598. Za tisti dan je bil izdan ukaz, da morajo vsi evangeličanski pridigarji in učitelji "pred sončnim zahodom« izginiti iz Ljubljane. Zadnji superintendent Felicijan Trubar (1555-1602), mlajši reformatorjev sin, se je tako moral izseliti. Prvega novembra 1598 je škof Tomaž Hren (1560-1630) zasedel ljubljansko špitalsko cerkev in dal kasneje na grmadi na Mestnem trgu zažgati več vozov s slovenskimi protestantskimi knjigami. To je bila smrtna ura za slovensko literaturo: Ivan Cankar, eden najpomembnejših slovenskih literatov, je ob 40o-letnici Trubarjevega rojstva zapisal, da je $\mathrm{z}$ reformacijo doseženi visoki ravni kulturnega življenja sledil "najbolj črn mrak", v katerega je Slovence "znova potisnila" protireformacija (Cankar [1908] 2008, 247-48). Protestantske postile, molitveniki, pesmarice in katekizmi so bili v Vojvodini Krajnski uničeni. Preživela je lahko le Dalmatinova Biblija, ki so jo uporabljali 
tudi v Rimskokatoliški cerkvi. Slovenski reformacijski tisk je preživel le v Prekmurju, ki je spadalo pod Ogrsko, in v luteranski enklavi Agoritschah/Zagoriče na južnem Koroškem, kjer je skrivaj nudil duhovno hrano tam skritemu in prikritemu kriptoprotestantizmu (Schwarz 2008, 340-42). Protestantska literatura je do skritih protestantov sicer prihajala po tihotapskih poteh iz Nemčije (Hüttl-Hubner 2003, 112; Bünker in Leuthold 2008). Iz nasprotne smeri je prišel na Koroško slovenski katekizem, natisnjen leta $1580 \mathrm{v}$ Mandeljčevi tiskarni v Ljubljani. Edini ohranjeni izvod tega katekizma lahko občudujemo v diecezanskem muzeju v Fresachu (Sakrausky [1960] 1981).

Namen tega prispevka je bil poudariti enormni pomen reformatorskega tiska za slovensko duhovno in kulturno zgodovino. Z njim je bil ustvarjen »kompleten instrumentarij knjižnega jezika« s slovnico (Bohorič 1584) in slovarjem (Megiser 1592), kodificiranim jezikom, pravnim besedilom (Cerkveni red 1564), šolskimi knjigami, pesmarica$\mathrm{mi}$, postilami, katekizmi, koledarji in $\mathrm{z}$ drugimi religioznimi besedili, skupaj 56 bibliografskih enot (Hüttl-Hubert 2003, 117). Trubarjevih dosežkov pa ne smemo omejevati le na lingvistično raven, saj je bil glavni motiv njegove jezikovne dejavnosti in ustvarjalnosti verski: vodilo ga je misijonarsko prizadevanje, da bi spoznanja reformacije približal slovenskemu ljudstvu (Giesemann 2017, 36). Čeprav je bil večji del reformatorskega tiska $\mathrm{v}$ času protireformacije uničen, je preživela Dalmatinova Biblija, "največji filološki dosežek mlade nacije« (HüttlHubert 2003, 117), ki je postal izhodišče modernega slovenskega knjižnega jezika.

Vpliv na hrvaško literaturo je komaj opazen (Weismann 1986, 36). Misijonski nameni biblijskega zavoda v Urachu pa so segali daleč preko Hrvaške in merili tudi na spreobrnitev Turkov. Da so te knjige prihajale tudi do njih, lahko sklepamo iz poročil iz Carigrada Ungnadu in vojvodi Krištofu (Saria 1969, 67). Reformacija ni ostala nemški dogodek, prodrla je tudi v slovanski svet in preko »Windische, Chrabatische un Cyrulische Truckherey« dosegla celo Carigrad/Istanbul. 


\section{VIRI IN LITERATURA}

Ahačič, Kozma. 2014. "Neue Entdeckungen und Erkentnisse zum slowenischen Protestantismus." Zeitschrift für Slawistik 59 (3): 285-98.

Baum, Wilhelm. 1991. »Der Klagenfurter Universitätsplan des Flacius Illiricus (1562) und der Flacianismus in Karnten."V Kollegium - Lyceum - Gymnasium: Vom "Collegium Sapientiae et Pietatis « zum Bundesgymnasium Völkermarkter Ring, ur. Wilhelm Baum, 33-44. Klagenfurt: Kärntner Druck- und Verlagsgesellschaft m. b. H.

Benga, Daniel. 2003. "Die erste bekannte Beschreibung der Ostkirchen durch einen Reformator: Primus Trubers Wahrnehmung der Kirchen des Ostens."Zeitschrift für bayerische Kirchengeschichte 72: 55-69.

Benz, Ernst. (1939) 1949. »Hans von Ungnad und die Reformation unter der Südslawen: Über die religiösen und sprachtheologischen Motive der südslawischen Übersetzungen und Drucke der Reformationszeit." V Ernst Benz, Wittenberg und Byzanz: Zur Begegnung und Auseinandersetzung der Reformation und der ostlich-ortodoxen Kirche, 141-208. Marburg: Elwert-Gräfe und Unzer Verlag.

Berčič, Branko. 1968. "Das slowenische Wort in den Drucken des 16. Jahrhunderts." V Abhandlungen über die slowenische Reformation: Literatur, Geschichte, Sprache, Stilart, Musik, Leksikographie, Theologie, Bibliographie (Geschichte, Kultur und Geisteswelt der Slowenen 1), ur. Branko Berčič, 152-261. München: Dr. Dr. Rudolf Trofenik

Brecht, Martin, in Hermann Ehmer. 1984. Südwestdeutsche Reformationsgeschichte: Zur Einführung der Reformation im Herzogtum Württemberg 1534. Stuttgart: Calwer Verlag.

Bünker, Michael, in Margit Leuthold, ur. 2008. Der Weg des Buches: Auf den Wegen der Bibelschmuggler durch Österreich. Salzburg: Edition Tandem.

Cankar, Ivan. 2008. Weiße Chrysantheme: Kritische und politische Schriften. [Aus dem Slowenischen mit Anmerkungen und einem Nachwort von Erwin Köstler.] Klagenfurt-Celovec: Drava Verlag.

Claus, Helmut. 2013. »,Gedruckt in Siebenbürgen durch Jernej Skuryaniz'." Gutenberg-Jahrbuch 88: 127-38.

Dolinar, Darko, in Karl W. Schwarz. 2016. »Theodor Elze.» V Enzyklopädie der slowenischen Kulturgeschichte in Kärnten/Koroška 1: A-I, ur. Katja Sturm-Schnabl in Bojan Ilija Schnabl, 311. Wien-Koln-Weimar: Böhlau Verlag.

Ehmer, Hermann. 2011. »Primus Truber, Hans Ungnad von Sonnegg und die Uracher Druckerei 1560-1564."V Primus Truber 1508-1586: der slowenische Reformator und Württemberg, ur. Sönke Lorenz, Anton Schindling in Wilfried Setzler, 201-16. Stuttgart: W. Kohlhammer. 
Elze, Theodor. 1894. »Die slowenischen protestantischen Ritual-, Streit-, Lehr- und Bekenntnisschriften des 16. Jahrhunderts."Jahrbuch für die Geschichte des Protestantismus in Österreich 15: 135-51.

---. 1895. »Die slowenischen protestantischen Bibelbücher des XVI. Jahrhundert.» Jahrbuch für die Geschichte des Protestantismus in Österreich 16: 117-75.

---. (1897) 2017. Primus Trubers Briefe: mit den dazu gehörigen Schriftstücken gesammelt und erläutert. (Tübingen) Norderstedt: Books on Demand.

Ernst, Anita, in Alexander Hanisch-Wolfram. 2011. »Das evangelische Diözesanmuseum Fresach."V Glaubwürdig bleiben: 500 Hundert Jahre protestantisches Abenteuer; Wissenschaftlicher Begleitband zur Kärntner Landesausstellung 2011 in Fresach. (Archiv für Vaterländische Geschichte und Topographie 101), ur. Wilhelm Wadl, 488-504. Klagenfurt: Kärntner Landesarchiv.

Giesemann, Gerhard. 2017. Die Theologie des slowenischen Reformators Primož Trubar. Köln: Böhlau Verlag.

Golec, Boris. 2011. »Neue Erkentnisse über die Herkunft und Identität vom Primus Truber/Primož Trubar.«V Primus Truber 1508-1586: Der slowenische Reformator und Württemberg, ur. Sönke Lorenz, Anton Schindling in Wilfried Setzler, 79-92. Stuttgart: W. Kohlhammer.

Grdina, Igor. 2006. "Reformationsströme im slowenischen Raum im 16. Jahrhundert." V Biblia Slavica 4: Südslawische Bibeln 3/2; Kommentare, ur. Jože Krašovec, Majda Merše in Hans Rothe, 9-12. Paderborn-München-Wien-Zürich: Ferdinand Schöningh.

Grdina, Igor, in Jonatan Vinkler, ur. 2005. Zbrana dela Primoža Trubarja 3. Ljubljana: Rokus in Slovensko protestantsko društvo Primož Trubar.

Grüll, Tibor, in István Monok. 1992. »Der Katalog der Ungnad-Truber Druckerei in Urach im Bestand des Stadtarchivs von Sopron (Ödenburg).« Wolfenbütteler Notizen zur Buchgeschichte 17 (1): 77-81.

Hanisch-Wolfram, Alexander, in Veronika Pflaum. 2012. "Primož Trubar: Spracheiniger und Reformator.« Ausstellung im Evangelischen Diözesanmuseum Fresach, 27. April-31. Oktober 2012, Fresach, Evangelisches Kulturzentrum.

Heilingsetzer, Lorenz, ur. 2005. Treffenliche schöne Biecher: Hans Ungnads Geschenk und die Universitätsbibliothek Basel im 16. Jahrhundert (mit einem Ausblick auf spätere Geschenke). Basel: Schwabe Verlag.

Hüttl-Hubert, Eva. 200o. »Slavica im Fokus: Zur Osteuropa-Kompetenz der Österreichischen Nationalbibliothek.«V Der Grenzgänger: Festschrift für Hans Marte, ur. Erhard Busek, 30-46. Klagenfurt: Wieser Verlag.

---. 2003. »,verborgen mit gfar: Die Anfänge der slowenischen Bibel.« Biblos 52: $87-120$. 
---. 2004. »Mehr als ein Ort der Erinnerung: Die Österreichische Nationalbibliothek und ihre Slavica." Biblos 53: 93-108.

---. 2007. »Die Österreichische Nationalbibliothek als Werkstätte slowenischer Forschung." Wiener Slavistisches Jahrbuch 53: 213-27.

---. 2011. »Anmerkungen zu Struktur, Provenienz und Rezeption der südslawischen Protestantica in der Österreichischen Nationalbibliothek. "V Die Reformation in Mitteleuropa. Internationales wissenschaftliches Symposium anlässlich des 500. Geburtstages von Primus Truber 2008, ur. Vincenc Rajšp, Karl W. Schwarz, Bogusław Dubaš in Christian Gastgeber, 37-62. Wien: Österreichische Akademie der Wissenschaften; Ljubljana: Založba ZRC, ZRC SAZU.

Ilić, Luka. 2008. »Primus Truber (1508-1586), the Slovenian Luther.« Lutheran Quarterly 23: 268-77.

---. 2014. »Matthias Flacius Illyricus.« V Das Reformatorenlexikon, ur. Irene Dingel in Volker Leppin, 116-22. Darmstadt: Wissenschaftliche Buchgesellschaft (WBG).

---. 2016. »Calvin, Flacius, Nidbruck and Lutheran Historiography.«V Calvinus Pastor Ecclesiae: Papers of the 11th International Congress on Calvin Research, ur. Hermann J. Selderhuis in Arnold Huijgen, 319-32. Göttingen: Vandenhoeck \& Ruprecht.

Ilić, Luka, in Angela Ilić. 2017. »Primus Truber und Anfänge der lutherischen Kirche in Slowenien." Ost-West: Europäische Perspektiven 18 (2): 116-23.

Immler, Gerhard, ur. 2007. Blicke über die Alpen: Ein Streifzug durch die Geschichte der bayerisch-slowenischen Beziehungen; Eine Ausstellung des Bayerischen Hauptstaatsarchivs. München: Staatliche Archive Bayerns.

Javoršek, Jože. 2011. Primož Trubar: Aus dem Slowenischen Richard Götz und Metka Wakounig; Mit einer Einleitung von Karl W. Schwarz. Klagenfurt/Celovec: Wieser.

Jembrich, Alojz. 1995. »Divergenzen in der Sprachauffassung Primus Trubers und Stephan Konsuls in Ungnads ,Bibelanstalt'." V Ein Leben zwischen Laibach und Tübingen. Primus Truber und seine Zeit. Intentionen, Verlauf und Folgen der Reformation in Württemberg und Innerösterreich, ur. Wolf Dieter Kluge, 452-69. München: Sagner.

Jerše, Sašo. 2013. »Die slowenische Reformation zwischen dem Amboss Christi und dem Hammer der Romantik - zur Hagiographie der Moderne und deren premodernen Grenzen." Jahrbuch für die Geschichte des Protestantismus in Österreich 129: $128-50$.

Jesenšek, Marko. 2011. »Trubar und die Entwicklung der slowenischen Sprache.« V Die Reformation in Mitteleuropa. Internationales wissenschaftliches Symposium anlässlich des 50o. Geburtstages von Primus Truber 2008, ur. Vincenc Rajšp, Karl W. Schwarz, Bogusław Dubaš in Christian Gastgeber, 303-11. Wien: Österreichische Akademie der Wissenschaften; Ljubljana: Založba ZRC, ZRC SAZU. 
Katičić, Radoslav. 2007. »Zur Polemik von Primus Truber mit Paulus Skalich.« Wiener Slavistisches Jahrbuch 53 (53): 55-66.

Kerševan, Marko. 2013. "Primus Trubers ,Kirche Gottes der slowenischen Sprache und ,Volk der slowenischen Sprache' " Carinthia I 203: 155-65.

Kidrič, France. 1919. Die protestantische Kirchenordnung der Slowenen im XVI. Jahrhundert: Eine literarisch-kulturhistorisch-philologische Untersuchung. Heidelberg: Carl Winter's Universitätbuchhandlung.

Kluge, Wolf Dieter, ur. 1995. Ein Leben zwischen Laibach und Tübingen. Primus Truber und seine Zeit. Intentionen, Verlauf und Folgen der Reformation in Württemberg und Innerösterreich. München: Sagner.

Knüppel, Michael. 2004. "Zum Problem der türkischen Bibelübersetzung des Hans Ungnad von Sonneck." Zeitschrift für Kirchengeschichte 115 (1/2): 100-16.

Kohnle, Armin. 2011. »Der Drucker und Buchhändler Johannes Manlius als Förderer der Reformation in Krain und Ungarn." V Primus Truber 1508-1586: Der slowenische Reformator und Württemberg, ur. Sönke Lorenz, Anton Schindling in Wilfried Setzler, 217-26. Stuttgart: Kohlhammer Verlag.

Kostrenčić, Ivan. 1874. Urkundliche Beiträge zur Geschichte der protestantischer Literatur der Südslawen in den Jahren 1559-1565. Wien: Carl Gerold's Sohn.

Köhler, Hans-Joachim, ur. 1981. Flugschriften als Massenmedium der Reformationszeit, Spätmittelalter und Frühe Neuzeit 13. Stuttgart: Ernst Klett Verlag.

Lagler, Wilfried. 2011. "Kurzübersicht über die zu seinen Lebzeiten im Druck erschienenen Werke Primus Trubers. «V Primus Truber 1508-1586: Der slowenische Reformator und Württemberg, ur. Sönke Lorenz, Anton Schindling in Wilfried Setzler, 145-200. Stuttgart: Kohlhammer Verlag.

Lang, Helmut W. 2017. »Idealist? Opportunist? Illegale Reformationsdrucke aus der Druckerei Johann Singriener in Wien.«V Brennen für den Glauben: Wien nach Luther, ur. Karl Vocelka, Rudolf Leeb in Walter Ohlinger, 128-49. Wien: Residenz Verlag.

Leeb, Rudolf. 2009. »Die Missionsgedanke bei Hans Ungnad von Soneck, Primus Truber und in der lutherischen Reformation." V Vera in hotenja: Študije o Primožu Trubarju in njegovem času, ur. Sašo Jerše, 255-72. Ljubljana: Slovenska matica.

Lorenz, Sönke, Anton Schindling in Wilfried Setzler, ur. 2011. Primus Truber: Der slowenische Reformator und Württemberg. Stuttgart: Kohlhammer Verlag.

Lukan, Walter. 1994. »Kopitars Privatbibliothek.«V Jernej Kopitar: Neue Studien und Materialien anlässlich seines 150. Todestages, ur. Walter Lukan, 589-705. Wien: Österreichisches Ost- und Südosteuropa-Institut.

Mezler-Andelberg, Helmut J. (1978) 1994. "Der Obrigkeit gehorsam: Zur Gegenreformation in Innerösterreich." V Helmut J. Mezler-Andelberg, Kirche in der Steiermark: Gesammelte Aufsätze, 211-30. Wien: Böhlau. 
Moeller, Berndt. 1979. "Stadt und Buch. Bemerkungen zur Struktur der reformatorischen Bewegung in Deutschland." V Stadtbürgertum und Adel in der Reformation, ur. Wofgang J. Mommsen, 25-39. Stuttgart: Klett-Cotta.

Murko, Matija. 1927. Die Bedeutung der Reformation und Gegenreformation für das geistige Leben der Südslaven. Prag-Heidelberg: Winter Verlag.

Oppitz, Ulrich, in Christoph Weismann. 2014. »Die slowenische Kirchenordnung von 1564 - ein neu gefundenes Exemplar.« Gutenberg-Jahrbuch 89: 185-88.

Pogačnik, Jože, ur. 1968. Freisinger Denkmäler. (Geschichte, Kultur und Geisteswelt der Slowenen 2). München: Dr. Dr. Rudolf Trofenik.

Prijatelj, Ivan. (1908) 1997. O kulturnem pomenu slovenske reformacije. Ljubljana: Mladinska knjiga.

Rajhman, Jože. 1986. Pisma Primoža Trubarja. Ljubljana: Slovenska akademija znanosti in umetnosti.

Rajšp, Vincenc, Karl W. Schwarz, Bogusław Dubaš in Christian Gastgeber, ur. 2011. Die Reformation in Mitteleuropa/Reformacija v srednji Evropi: Beiträge anlässlich des 50o. Geburtstag vom Primus Truber. Wien: Österreichische Akademie der Wissenschaften; Ljubljana: Založba ZRC, ZRC SAZU.

Reingrabner, Gustav. 2007. Um Glaube und Freiheit: Eine kleine Rechtsgeschichte der Evangelischen in Österreich und ihrer Kirche. Frankfurt am Main: Peter Lang.

Rothkegel, Martin. 2004. "Von der schönen Madonna zum Scheiterhaufen: Gedenkrede auf Balthasar Hubmaier." Jahrbuch für die Geschichte des Protestantismus in Österreich 120: 49-73.

Rupel, Mirko. 1965. Primus Truber: Leben und Werk des slowenischen Reformator. Deutsche Übersetzung und Bearbeitung von Balduin Saria. München: Südosteuropa Verlagsgesellschaft.

Sakrausky, Oskar. (1970) 1981. »Der Einfluss der deutschen Theologie auf die südslawische Reformation." Carinthia I 171: 291-341.

---. (1960) 1981. „Ein bisher unbekannter slowenischer protestantischer Katechismus aus dem Jahre 1580." Carinthia I 171: 159-69.

---. (1968) 1981. "Theologische Strömungen in der reformatorischen Literatur der Slowenen und Kroaten. "Carinthia I 171: 315-31.

---. (1976) 1981. »Die Theologische Bedeutung der Bibelübersetzung Jurij Dalmatins.» Carinthia I 171: 349-79.

---, ur. 1989. Primus Truber: Deutsche Vorreden zum slowenischen und kroatischen Reformationswerk. Wien: Evangelischer Presseverband.

Saria, Balduin. 1969. »Die Reformation im südslawischen Raum«. Kirche im Osten 12: 58-77. 
Schindling, Anton. 2014. "Primus Truber.« V Das Reformatorenlexikon, ur. Irene Dingel in Volker Leppin, 247-52. Darmstadt: Wissenschaftliche Buchgesellschaft (WBG).

---. 2011. »Die Habsburger, das Reich, die Erblande und Reformation.«V Primus Truber 1508-1586: Der slowenische Reformator und Württemberg, ur. Sönke Lorenz, Anton Schindling in Wilfried Setzler, 287-301. Stuttgart: Kohlhammer Verlag.

---. 2013. »Primus-Truber-Gedenkorte in Süddeutschland.» Carinthia I 203: 167-83.

---. 2016. »Primus Truber/Primož Trubar, ein slawischer Reformator in Württemberg." V Искусство и культура Европы эпохи Возрождения и раннего Нового времени: Сборник трудов в честь Всеволода Матвеевича Володарского, ur. Кудрявцев, О. Ф. et al., 178-87. Москва, Санкт-Петербург: Центр гуманитарных инициатив.

Schnurrer, Christian Friedrich. (1799) 1989. Slavischer Bücherdruck in Württemberg im 16. Jahrhundert: Ein literarischer Bericht. (Geschichte, Kultur und Geisteswelt der Slowenen 20). München: Dr. Dr. Rudolf Trofenik.

Schorn-Schütte, Luise, ur. 2005. Das Interim 1548/50: Herrschaftskrise und Glaubenskonflikt. Gütersloh: Gütersloher Verlagshaus.

Schwarz, Karl W. 2015. »Truberiana aus Memmingen, Schwäbisch Hall, Tübingen und Wien: Erfreuliches und betrübliches aus der aktuellen Truberforschung." Historia Ecclesiastica 6: 3-15.

---. 2008. »Agoritschach/Zagoriče - eine evangelische Gemeinde in gemischtsprachigen Südkärnten.» Carinthia I 198: 333-52.

---. 2016. »Dalmatinbibel.«V Enzyklopädie der slowenischen Kulturgeschichte in Kärnten/Koroška 1: A-I, ur. Katja Sturm-Schnabl in Bojan Ilija Schnabl, 233-34. Wien-Koln-Weimar: Böhlau Verlag.

Setzler, Wilfried. 2011. "Gedächtnisort Burgsteige.« V Primus Truber 1508-1586: Der slowenische Reformator und Württemberg, ur. Sönke Lorenz, Anton Schindling in Wilfried Setzler, 418-19. Stuttgart: Kohlhammer Verlag.

Simoniti, Primož. 2008. Humanismus bei den Slowenen: Slowenische Humanisten bis zur Mitte des 16.Jahrhundert. Ur. Marija Wakounig, prev. Jože Wakounig. Wien: Verlag der Österreichischen Akademie der Wissenschaften.

Stökl, Gunther. 1940. Die deutsch-slavische Südostgrenze des Reiches im 16.Jahrhundert: Ein Beitrag zu ihrer Geschichte dargestellt an Hand des südslavischen Reformationsschriftum. Breslau: Priebatsch.

Suppan, Arnold. 2002. Deutsche Geschichte im Osten Europas: Zwischen Adria und Karawanken. Berlin: Siedler Verlag.

Trubar, Primož. (1564) 1973. Cerkovna ordninga/Slowenische Kirchenordnung. (Geschichte, Kultur und Geisteswelt der Slowenen 10). München: Dr. Dr. Rudolf Trofenik. 
---. (1564) 2005. Cerkovna ordninga. V Zbrana dela Primoža Trubarja 3, ur. Igor Grdina in Jonatan Vinkler, 227-578. Ljubljana: Rokus in Slovensko protestantsko društvo Primož Trubar.

Vorndran, Rolf. 1977. Südslawische Reformationsdrucke in der Universitätsbibliothek Tübingen: Eine Beschreibung der vorhandenen glagolitischen, kyrillischen und anderen Drucke der »Uracher Bibelanstalt«. (Contubernium 24). Tübingen: J. C. B. Mohr.Weismann, Christoph. 1986. "Die Winden, Crabaten und Türken Bekehrung: Reformation und Buchdruck bei den Südslawen. « Kirche im Osten 29: 9-37.

---. 1972. »Die slowenische Kirchenordnung Primus Trubers 1564." Gutenberg-Jahrbuch 46: 197-210.

Zimmermann, Bernd. 1981. »Landeshauptmann Hans Ungnad von Sonnegg (14931564): Ein Beitrag zu seiner Biographie." V Siedlung, Macht und Wirtschaft: Festschrift Fritz Posch, ur. Gerhard Pferschy, 203-16. Graz: Steiermärkisches Landesarchiv.

Zorn, Aleksander, ur. 2008. Trubarjevo leto/The Year of Trubar/Das Trubar-Jahr. Ljubljana: Koordinacijski odbor za državne proslave.

Žnidaršič Golec, Lilijana. 2011. »Die ,Slowenische Kirchenordnung von 1564 zwischen Wunsch und Wirklichkeit." V Primus Truber 1508-1586: Der slowenische Reformator und Württemberg, ur. Sönke Lorenz, Anton Schindling in Wilfried Setzler, 103-15. Stuttgart: Kohlhammer Verlag.

https://doi.org/10.26493/2590-9754.14(28)61-82 